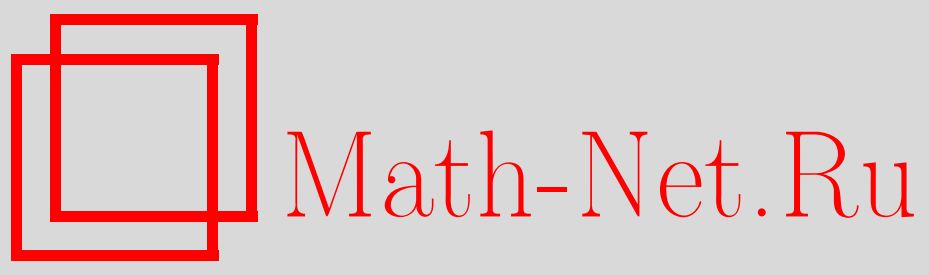

А. А. Аграчев, Д. В. Аносов, И. А. Богаевский, А. С. Бортаковский, А. Б. Будак, В. А. Васильев, В. В. Горюнов, С. М. Гусейн-Заде, А. А. Давыдов, В. К. Зародов, В. Д. Седых, Д. В. Трещёв, В. Н. Чубариков, Владимир Михайлович Закалюкин (некролог), УМН, 2012, том 67, выпуск 2, 187-190

DOI: https://doi.org/10.4213/rm9474

Использование Общероссийского математического портала Math-Net.Ru подразумевает, что вы прочитали и согласны с пользовательским соглашением http://www.mathnet.ru/rus/agreement

Параметры загрузки:

IP : 35.173 .219 .149

26 апреля 2023 г., 17:10:14

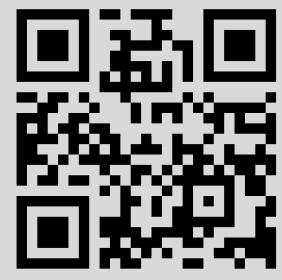




\section{Владимир Михайлович Закалюкин}

30 декабря 2011 г. в Москве скоропостижно скончался выдающийся российский математик Владимир Михайлович Закалюкин.

В.М. Закалюкин - яркий представитель всемирно известной математической школы В.И. Арнольда по теории особенностей и геометрической теории динамических систем. Он получил фундаментальные результаты в различных областях математики, включая классическую теорию особенностей, геометрическую теорию управления и параметрическую оптимизацию. Многие из них приобрели широкую известность и заслуженное признание отечественной и международной научной общественности и нашли приложения к анализу явлений различной природы. Результаты В. М. Закалюкина по перестройкам каустик и волновых фронтов стали классическими и вошли в учебники. Активно занимаясь математикой, Владимир Михайлович написал более шестидесяти научных работ, подготовил 5 кандидатов наук. В 2007 г. он был удостоен премии МАИК за лучшую публикацию в журналах РАН.

В. М. Закалюкин родился 9 июля 1951 г. в Москве. Его родители - Михаил Иванович Закалюкин (1916-1970) и Юлия Михайловна Бузярова (1919-1975) учились на отделении механики механико-математического факультета МГУ в довоенные годы. Во время войны Михаил Иванович работал в ЛИИ им. М. М. Громова, затем до 1965 г. в ВВИА им. Н.Е. Жуковского, а после - в МВТУ им. Н.Э. Баумана. Юлия Михайловна работала на кафедре теоретической механики МАИ. Оба они были кандидатами физико-математических наук, доцентами. По примеру родителей Владимир Михайлович всю свою сознательную жизнь посвятил математике и ее преподаванию.

В 1960-е годы Закалюкины снимали дачу под Звенигородом, где жил на даче знаменитый композитор Г. В. Свиридов, с которым М. И. Закалюкин очень дружил. Володя много общался со Свиридовым, под влиянием которого он увлекся классической музыкой и впоследствии часто слушал ее, занимаясь научной работой.

Математические способности проявились у Володи достаточно рано - к началу 7-го класса он с помощью отца выучил практически всю школьную программу по математике. В 1965 г. Володя поступил в 8-й класс московской физико-математической школы №2, которую он окончил в 1968 г. с серебряной медалью. Благодаря своему весьма разностороннему таланту учился он по всем предметам исключительно на "отлично", а в 9-м классе его сочинение по роману Л.Н. Толстого "Война и мир" было признано одним из лучших в районе.

В июле 1968 г. Володя сдавал вступительные экзамены на отделение математики механико-математического факультета МГУ. На устном экзамене по математике 
Володе достался вопрос, связанный с теорией числа. Он решил “блеснуть" и начал рассказывать аксиоматику числа, которая явно выходила за рамки программы экзамена, за что его и "погоняли" весьма основательно, но все завершилось благополучно Володя уверенно и быстро решил все предложенные дополнительные задачи и получил "отлично". Также получив пятерки по физике и за сочинение, В. М. Закалюкин был зачислен на мехмат МГУ.

Все 5 лет он учился исключительно на "отлично", часто сдавая сессию еще до ее начала. Иногда Володя, подготовившись самостоятельно по учебникам, сдавал экзамен чуть ли не в середине семестра, что, правда, не всегда удавалось с первого раза. За отличную учебу на 5-м курсе он был удостоен стипендии им. С. А. Чаплыгина. На младших курсах Володя начал посещать семинар В. И. Арнольда по теории особенностей, а на третьем курсе Владимир Игоревич стал его научным руководителем. В 1973 г. В. М. Закалюкин, опубликовав несколько научных работ, блестяще окончил мехмат и поступил в аспирантуру на кафедру дифференциальных уравнений.

K сожалению, родители Володи оба умерли очень рано, из-за чего он в 1975 г. после смерти мамы перешел в заочную аспирантуру и стал работать ассистентом кафедры теоретической механики МАИ. Защитив в 1978 г. на мехмате МГУ кандидатскую диссертацию "Особенности лагранжевых и лежандровых отображений" под руководством В. И. Арнольда, В. М. Закалюкин в 1980 г. перешел на должность старшего преподавателя той же кафедры, а в 1981 - на должность доцента. В МАИ В. М. с блеском читал лекции по теоретической механике и механике сплошных сред, подготовил курс "Применение теории особенностей к динамическим системам", активно занимался научной работой со студентами и аспирантами, подготовил двух кандидатов наук, а двух своих учеников рекомендовал для обучения в аспирантуре мехмата МГУ. В 1999 г. за большие заслуги в учебной и научной работе Владимир Михайлович был переведен на должность профессора.

После этого он очень скоро защитил докторскую диссертацию “Локальные особенности в симплектических и контактных пространствах" в Математическом институте им. В.А. Стеклова, и в 2000 г. ему были присуждены степень доктора физикоматематических наук и звание профессора. Научные связи Владимира Михайловича с Математическим институтом были очень тесными: он часто выступал на конференциях и семинарах, участвовал в организации конференций, проводимых в институте, опубликовал несколько статей в Трудах МИАН.

В 1980 г. В. М. Закалюкин возглавил экзаменационную комиссию МАИ по математике и на долгие годы определил порядок и стиль ее работы. Он умело руководил большим коллективом преподавателей, успешно сочетая высокие требования к качеству выполняемой работы с добрыми взаимоотношениями в коллективе. Неоспоримый авторитет Владимира Михайловича, его трудолюбие, чуткость, бодрое настроение и великолепное чувство юмора делали работу в комиссии привлекательной. И позже он все время оставался ее неформальным лидером, главным экспертом и консультантом. На протяжении 30 лет В. М. ежегодно придумывал порядка 50 нестандартных задач по всем разделам элементарной математики, в которых оригинальные идеи и формулировки сочетались с наличием решений школьными методами. Появившись на вступительных экзаменах в МАИ, эти нестандартные задачи (как правило, без указания авторства) включались затем в различные пособия, а некоторые из них использовались на олимпиадах различных уровней. В. М. Закалюкин написал 3 учебных пособия для абитуриентов, одно из которых выдержало 7 изданий, являясь на протяжении многих лет основным задачником по математике на подготовительных курсах МАИ.

Во всех начинаниях кафедры теоретической механики МАИ В. М. Закалюкин принимал самое активное участие. Человек редкого обаяния, обладающий оригинальным чувством юмора, он был душой всего коллектива кафедры. Даже после ухода в МГУ Владимир Михайлович работал на полставки профессора и оставался чле- 
ном кафедры, куда очень охотно приходил и где очень радушно встречался со всеми сотрудниками.

В 2000 г. Владимир Михайлович перешел на должность профессора только что созданной кафедры теории динамических систем мехмата МГУ. С первых дней основания кафедры он вел большую работу по организации ее деятельности, а с 2002 г. занимал должность заместителя заведующего кафедрой. На мехмате В. М. Закалюкин с блеском читал курс "Обыкновенные дифференциальные уравнения" и спецкурс "Введение в теорию особенностей", подготовил трех кандидатов наук. Благодаря своим человеческим качествам, исключительным доброжелательности и щедрости, чувству юмора и неизменному оптимизму, В. М. пользовался большой любовью коллег и учеников и редкой популярностью среди студентов.

С 2001 г. В. М. Закалюкин с успехом совмещал свою активную преподавательскую деятельность в Москве с работой на должности профессора Ливерпульского университета, где тоже был очень популярным лектором и руководил двумя аспирантами.

Наряду с активными занятиями математикой В. М. Закалюкин много времени уделял и организации математической жизни. Он был одним из руководителей семинара В. И. Арнольда на мехмате МГУ в весенних семестрах с начала 90-х годов, состоял в редколлегиях журналов "Функциональный анализ и его приложения" и "Journal of Dynamical and Control Systems", входил в организационные и программные комитеты многих конференций, в частности, активно занимался организацией конференций в Суздале. С 2002 г. Владимир Михайлович постоянно избирался членом правления Московского математического общества. Он был руководителем и участником множества российских и международных научных проектов в области теории особенностей, оптимального управления и распознавания образов.

В. М. Закалюкин получил мировую известность благодаря своим замечательным работам по теории лагранжевых и лежандровых особенностей. Он разработал методы, с помощью которых продолжил классификацию особенностей общих лагранжевых и лежандровых отображений, начатую его учителем В. И. Арнольдом. В. М. получил список нормальных форм функции времени для устойчивого квазиоднородного фронта и типичной каустики, имеющей лишь особенности серий $A$ и $D$. Эти результаты и методы, давно ставшие классическими, он использовал при решении важных прикладных задач теории особенностей, в частности, при классификации особенностей выпуклых оболочек гладких многообразий, при изучении контактов гладких многообразий с флагами, при описании свойств лагранжева отображения, близкого к коллапсу, а также в работах по классической механике и теории оптимального управления.

В середине 90-х годов В.М. заинтересовался субримановыми пространствами и связанными с ними вопросами геометрии, анализа и математической теории управления. Хотя его первая работа в этой области касалась хорошо знакомой ему темы устойчивости каустик и волновых фронтов, технику пришлось изобретать совершенно новую, поскольку гамильтонианы субримановых метрик общего положения весьма далеки от гамильтонианов общего положения в общепринятом смысле. "Большой фронт" оказался устойчивым, а вот каустика нет, причем В. М. нашел очень красивый способ построения модулей.

Затем последовал большой цикл работ с Ж.-П. Готье о метрической сложности и асимптотически оптимальной аппроксимации кривых в субримановых пространствах. Это было совсем новое поле деятельности для В.М. Почти все пришлось изобретать заново, но его увлекло сочетание геометрической красоты задачи с большими возможностями для конкретных инженерных приложений. Последние еще не опубликованные работы открыли новую красивую главу геометрии плоских кривых: исходная задача свелась к описанию замкнутых плоских кривых, чья кривизна есть полином заданной степени от координат. Для степени 0 получаем окружности и пря- 
мые, а для степени 1 - эйлеровы эластики, имеющие форму восьмерки. Закалюкин и Готье нашли такие кривые для всех степеней.

Во второй половине 90-х годов В. М. Закалюкин занимался приложениями теории особенностей гладких отображений к параметрической оптимизации. В частности, ему совместно с А. А. Давыдовым удалось расклассифицировать типичные точечные особенности условного минимума при трех и четырех параметрах, а также доказать их устойчивость и стабилизацию при росте числа переменных.

В последние годы Владимир Михайлович вместе со своим аспирантом А. Н. Курбацким изучал зоны локальной управляемости трехмерных управляемых систем. Для типичных систем они доказали устойчивость границы этой зоны и расклассифицировали ее особенности.

В Ливерпуле В. М. Закалюкин был инициатором совместных работ с Б. Брюсом и В. В. Горюновым по топологическому осмыслению простых матричных особенностей, которые увенчались их элегантной классификацией подгруппами групп Вейля. Продолжением этого направления была работа об устойчивости особых лагранжевых и лежандровых подмногообразий, определяемых версальными деформациями сложных функций.

Довольно большая серия работ В. М. Закалюкина с П. Гиблином и их ливерпульскими аспирантами посвящена особенностям множеств аффинных центров симметрии. Эта тематика возникла при компьютерном распознавании образов, а ее результаты в основном были экспериментальными и ограничивались многочисленными картинками, красивыми и загадочными. В. М. быстро увидел их связь с лагранжевыми и лежандровыми отображениями, что позволило расклассифицировать устойчивые особенности множеств центров симметрии в малых размерностях. Полученные результаты В. М. эффективно приложил к задачам теории управления и финслеровой геометрии.

Последние годы Владимира Михайловича были чрезвычайно плодотворными и разносторонними в творческом отношении. В работе была масса разнообразных проектов по различным тематикам, как самостоятельных, так и с рядом соавторов. Многое осталось незавершенным, а что-то и только начатым. Все это, как и его научное наследие в целом, будет, безусловно, жить и развиваться дальше его коллегами и учениками.

Владимир Михайлович отличался исключительной доброжелательностью к окружающим. Он всегда откликался на любую просьбу, был готов помочь насколько это возможно. Работая в коллективе, он многое брал на себя, не жалея своего собственного времени, что создавало весьма положительный настрой, и люди включались и работали как следует.

Владимир Михайлович быстро становился центром любой компании, любил рассказывать массу забавных историй из своей жизни и жизни других математиков. Он участвовал в работе многих конференций не только как замечательный докладчик, но и как организатор разнообразных мероприятий культурного характера. Так на регулярных конференциях по геометрии и топологии каустик в Варшаве он устраивал ежевечерние многочасовые прогулки по ближайшим паркам. Владимир Михайлович рассказывал, что теорию лагранжевых и лежандровых особенностей он придумал, катаясь на коньках в Нескучном саду недалеко от своего дома.

Ушел из жизни удивительный, ни на кого не похожий, яркий, талантливый, щедрый человек. Его некем заменить, остается только помнить и по мере сил равняться на его светлый образ.

А.А. Аграчев, Д.В. Аносов, И.А. Богаевский, А.С. Бортаковский, А.Б. Будак, В.А. Васильев, В. В. Горюнов, С.М. Гусейн-Заде, А.А. Давъдов, В. К. Зародов, В. Д. Седых, Д. В. Трещёв, В. Н. Чубариков 